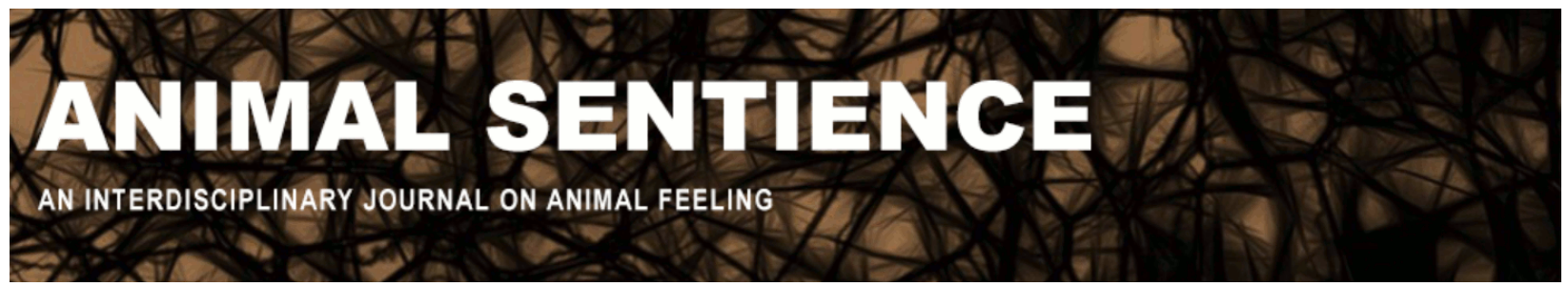

Horta, Oscar (2016) Changing attitudes towards animals in the wild and speciesism. Animal Sentience 7(15)

DOI: 10.51291/2377-7478.1109

Date of submission: 2016-05-28

Date of acceptance: 2016-07-05 (c) 


\title{
Changing attitudes towards animals in the wild and speciesism
}

Commentary on $\mathrm{Ng}$ on Animal Suffering

\author{
Oscar Horta \\ School of Philosophy \\ University of Santiago de Compostela
}

\begin{abstract}
I argue that despite $\mathrm{Ng}^{\prime}$ s claim that we should postpone the defense of those animals that live in the wild, we do have reasons to start spreading concern for them now. We can do it by (i) changing public attitude by heightening awareness of speciesism, by which we will also challenge animal exploitation; and (ii) by disseminating information about the situation of animals in the wild.
\end{abstract}

Oscar Horta studies normative and applied ethics, in particular animal ethics, speciesism, and disvalue in nature.

http://usc-es.academia.edu/OscarHorta

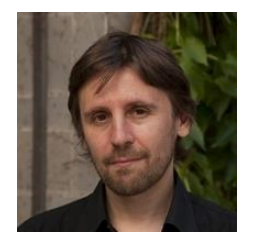

The contributions of professor Yew-Kwang $\mathrm{Ng}$ have been invaluable to many of us. In particular, his examination of the ratio of positive wellbeing and disvalue suffered by animals in the wild has been extremely influential to many animal ethicists among which I count myself. In his seminal paper "Toward Welfare Biology: Evolutionary Economics of Animal Consciousness and Suffering" ( $\mathrm{Ng} \mathrm{1995)} \mathrm{he} \mathrm{argued} \mathrm{that} \mathrm{animal} \mathrm{population} \mathrm{dynamics} \mathrm{indicate}$ that most animals who come into existence die shortly thereafter, having suffered a great deal. This happens as nonhuman animals typically face very harsh living conditions for natural reasons, such as lack of food, disease, hostile weather conditions, parasitism, attacks by other animals, and accidents. According to $\mathrm{Ng}$, this suggests suffering prevails over positive wellbeing in nature (Horta 2010; Faria \& Paez 2015; Tomasik 2015 [2009]). Ng has recently stated that he still agrees with this, and considers this issue very important (Carpendale 2015). However, in this new article Ng (2016) argues that animal advocates should focus on achieving certain changes in the exploitation of nonhuman animals by human beings, leaving for the future the protection of animals in the wild.

$\mathrm{Ng}$ is assuming that it is not realistic to make a significant difference for animals in nature right now. Despite this, there are already various ways in which we are currently aiding these animals. They include, among others, rescuing trapped animals and sheltering those in danger and suffering due to weather conditions (Bovenkerk et al. 2003); saving sick, injured and orphan animals (Delahay et al. 2009); rescuing animals in natural disasters (Anderson \& Anderson 2006); vaccinating animals against severe diseases (Blancou et al. 1988); and providing water and food to thirsty and starving animals (Smith 2001). All these actions and programs make an important difference for the animals involved. Still, they only help a tiny minority of those who need help. This is not just due to a lack of technical means, or of the knowledge needed to assess how to help some animals without harming others more. It is due, mainly, to a speciesist lack of concern for nonhuman animals (Sagoff 1984). In fact, it 
would be possible to help them much more if we wanted to do it. Moreover, there is also a serious risk that in the future we will have a far more significant capacity to aid animals in the wild yet fail to do it because we still have speciesist attitudes.

Raising awareness about speciesism can thus help us increase concern for animals living in nature. But note that it can also increase concern for those animals that are exploited by humans, thus helping us to challenge animal exploitation too. If this is correct, it counters $\mathrm{Ng}$ 's claim that it may be better to wait to protect wild animals until we have raised concern for those animals that are exploited by humans. The same general course of action can promote both aims at the same time.

There is, however, another reason many people think we need not aid animals in the wild (Morris \& Thornhill 2006). Many people (including academics and animal advocates) do not have a background in ecology and life history theory. As a result, they do not have a clear picture of what the situation of animals in nature really is. This suggests that in order to promote concern for animals in the wild, we should combine the case against speciesism with the dissemination of information about why suffering and early death are so prevalent in nature. This course of action seems to be fully in line with the ethical aims Ng $(1995 ; 2016)$ has defended (Carpendale 2015), even if it entails amending the strategical viewpoint he has defended in his 2016 target article.

\section{References}

Anderson, A. \& Anderson, L. (2006) Rescued: Saving animals from disaster. New World Library: Novato.

Blancou, J., Pastoret, P. P., Brochier, B., Thomas, I. \& Bögel, K. (1988) Vaccinating wild animals against rabies. Reviews in Science Technology, 7(4), 10005-10013.

Bovenkerk, B., Stafleu, F., Tramper, R., Vorstenbosch, J. \& Brom, F. W. A. (2003) To act or not to act? Sheltering animals from the wild: A pluralistic account of a conflict between animal and environmental ethics. Ethics, Place and Environment, 6, 13-26.

Carpendale, M. (2015) Welfare biology as an extension of biology. Interview with Yew-Kwang Ng. Relations: Beyond Anthropocentrism, 3, 197-202.

Delahay, R. J., Smith, G. C. \& Hutchings, M. R. (2009) Management of disease in wild mammals. Dordrecht: Springer.

Faria, C. \& Paez, E. (2015) Animals in need: The problem of wild animal suffering and intervention in nature. Relations: Beyond Anthropocentrism, 3, 7-13.

Horta, O. (2010) Debunking the idyllic view of natural processes: Population dynamics and suffering in the wild. Télos, 17, 73-88. 
Morris, Michael C. \& Thornhill, R. H. (2006) Animal liberationist responses to nonanthropogenic animal suffering. Worldviews, 10, 355-379.

Ng, Y.-K. (1995) Towards welfare biology: Evolutionary economics of animal consciousness and suffering. Biology and Philosophy, 10, 255-285.

$\mathrm{Ng}$, Y-K. (2016). How welfare biology and commonsense may help to reduce animal suffering. Animal Sentience 2016.007.

Sagoff, M. (1984) Animal liberation and environmental ethics: Bad marriage, quick divorce. Osgoode Hall Law Journal, 22, 297-307.

Smith, B. L. (2001) Winter feeding of elk in western North America. Journal of Wildlife Management, 65, 173-190.

Tomasik, B. (2015 [2009]) The importance of wild-animal suffering. Relations: Beyond Anthropocentrism, 3, 133-152. 